\title{
STUDIES OF BRAZILIAN METEORITES V. EVIDENCE FOR SHOCK METAMORPHISM IN THE PARANAÍBA, MATO GROSSO, CHONDRITE
}

\author{
K. KEIL*, E. KIRCHNER*(1), C. B. GOMES*(2), and J. NELEN**
}

\begin{abstract}
Mineral compositions, particularly of olivine $\left(\mathrm{Fa}_{23.7}\right)$, orthopyroxene $\left(\mathrm{Fs}_{20.7}\right)$, and chromite, and the bulk composition, especially the ratios $\mathrm{Fe}^{0} / \mathrm{Ni}^{0}(5.05), \mathrm{Fe}_{\text {total }} / \mathrm{SiO}_{2}(0.52)$, and $\mathrm{Fe}^{0} /$ $/ \mathrm{Fe}_{\text {total }}(0.31)$ and the contents of $\mathrm{Fe}_{\text {total }}(20.86 \%)$ and metallic nickel-iron $(7.92 \%)$, indicate that Paranaíba is an L-group chondrite. Homogeneous and uniform ferromagnesian minerals, scarcity of chondrules, and high degree of recrystallization suggest that it belongs to the petrologic class L6.

Dark veins and areas formed by extensive shock alteration ( $>430$ kilobars, $1500-1700^{\circ} \mathrm{C}$ ) with the angular to subrounded and rounded light fragments representing less altered portions of the original rock $\left(\sim 200\right.$ kilobars, $\left.<900^{\circ} \mathrm{C}\right)$. Light portions contain maskelynite and, in the dark veins, olivine and pyroxene were shock-transformed into isotropic to weakly anisotropic grains of essentially unaltered composition. Pressure gradients were high, even on a micron scale. Isotropic olivine is not ringwoodite, probably because the high temperature prohibited quench to preserve ringwoodite.
\end{abstract}

RESUMO Dados de química mineral (composição da olivina, $\mathrm{Fa}_{23,7}$; do ortopiroxênio, $\mathrm{Fs}_{20,7}$; e da cromita) e de química global (razões $\mathrm{Fe}^{0} / \mathrm{Ni}^{0}=5,05, \mathrm{Fe}_{\text {total }} / \mathrm{SiO}_{2}=0,52$ e $\mathrm{Fe}^{0} / \mathrm{Fe}_{\text {total }}=0,31$, além das concentrações de $\mathrm{Fe}_{\text {total }}=20,86 \%$ e de níquel-ferro $=7,92 \%$ ) são indicativos de que 0 meteorito Paranaiba pertence ao grupo $\mathrm{L}$ dos condritos. Por outro lado, evidências químicas (composição uniforme e homogênea dos minerais ferromagnesianos) e texturais (ausência quase que completa de côndrulos e alto grau de recristalização da matriz) sugerem que o meteorito pode ser incluído na classe petrológica $\mathbf{L} 6$.

Veios e áreas escuras formaram-se como resultado de intenso metamorfismo de choque $(>430$ quilobárias, $1500-1700^{\circ} \mathrm{C}$ ), com os fragmentos de coloração mais clara, em geral de forma angular a subangular, ou mesmo arredondada, representando as porções menos alteradas do material original ( $\sim 200$ quilobárias, $<900^{\circ} \mathrm{C}$ ). As partes claras contêm maskelynita e, no interior dos veios escuros, olivina e piroxênio transformaram-se em material isótropo a fracamente anisótropo, sem que tivesse ocorrido modificação significativa na composição química. Mesmo em pequena escala, os gradientes de pressão parecem ter sido elevados. A alta temperatura atingida no processo parece ter sido o fator responsável pela ausência, no meteorito, de ringwoodita, uma olivina isótropa.

INTRODUCTION The Paranaíba meteorite, also referred to as Can-Can and Mato Grosso, fell in 1956 near the village of Sant'Ana (approximate lat. $19^{\circ} 8^{\prime} \mathrm{S}$; long. $51^{\circ} 40^{\prime} \mathrm{N}$ ), about $70 \mathrm{~km} \mathrm{NW}$ of Paranaíba and $80 \mathrm{~km}$ from the mouth of Aporé river in the southern part of the State of Mato Grosso, Brazil. According to many witnesses, the fall was accompanied by loud buzzing noise. with the stone hitting a tree and penctrating about $2 \mathrm{~m}$ into the soil. Approximately $100 \mathrm{~kg}$ were recovered by local larmers.

*Department of Geology and Institute of Meteoritics, University of New Mexico, Albuquerque, New Mexico, 87131, USA

**Department of Mineral Sciences, Smithsonian Institution, National Museum of Natural History, Washington, D.C., 20560, USA

${ }^{(1)}$ Permanent address: Mineralogisches Institut, Universität Salzburg, Salzburg, Austria

(2) Permanent address: Instituto de Geociências, Universidade de São Paulo, São Paulo, Brasil 

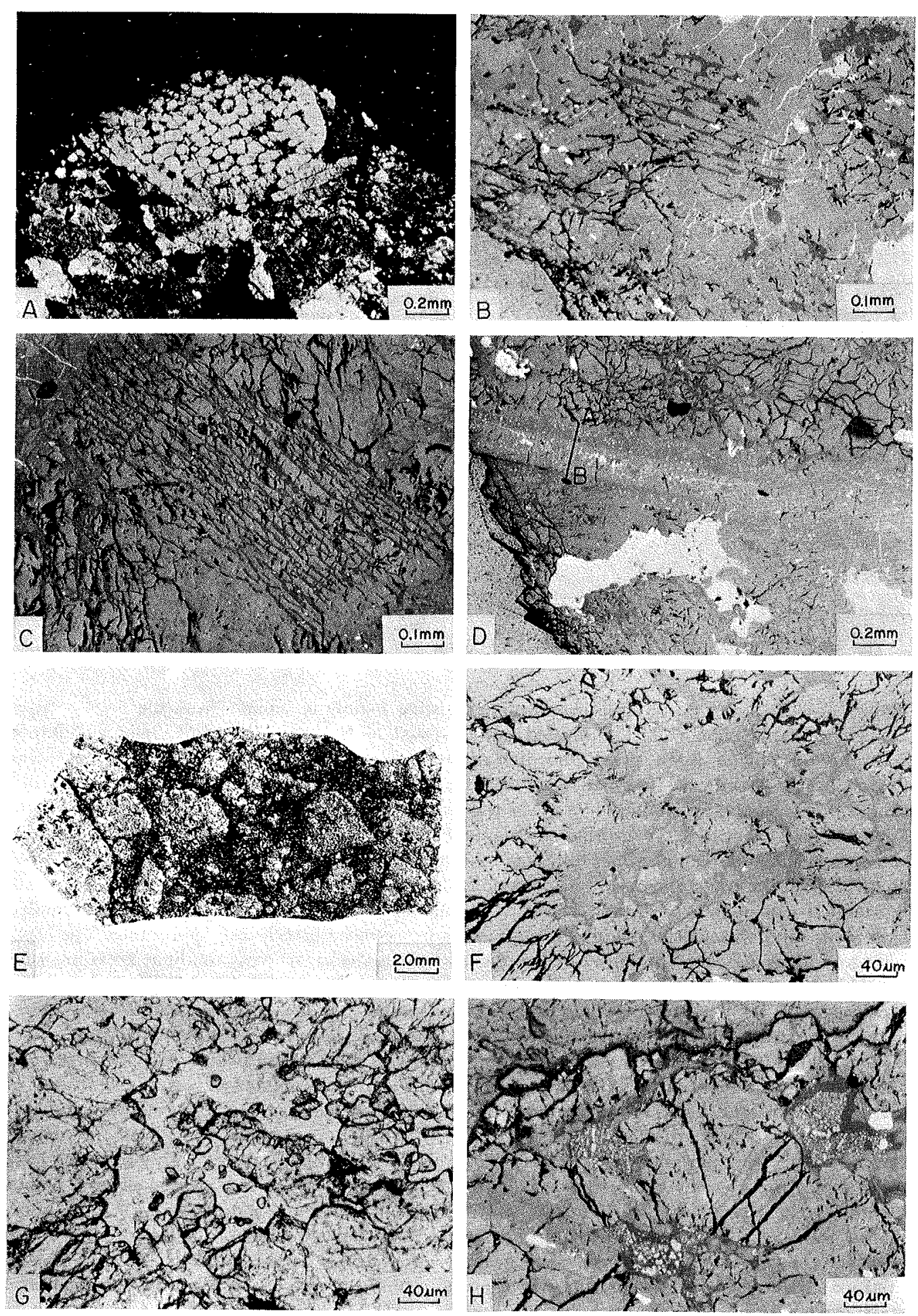

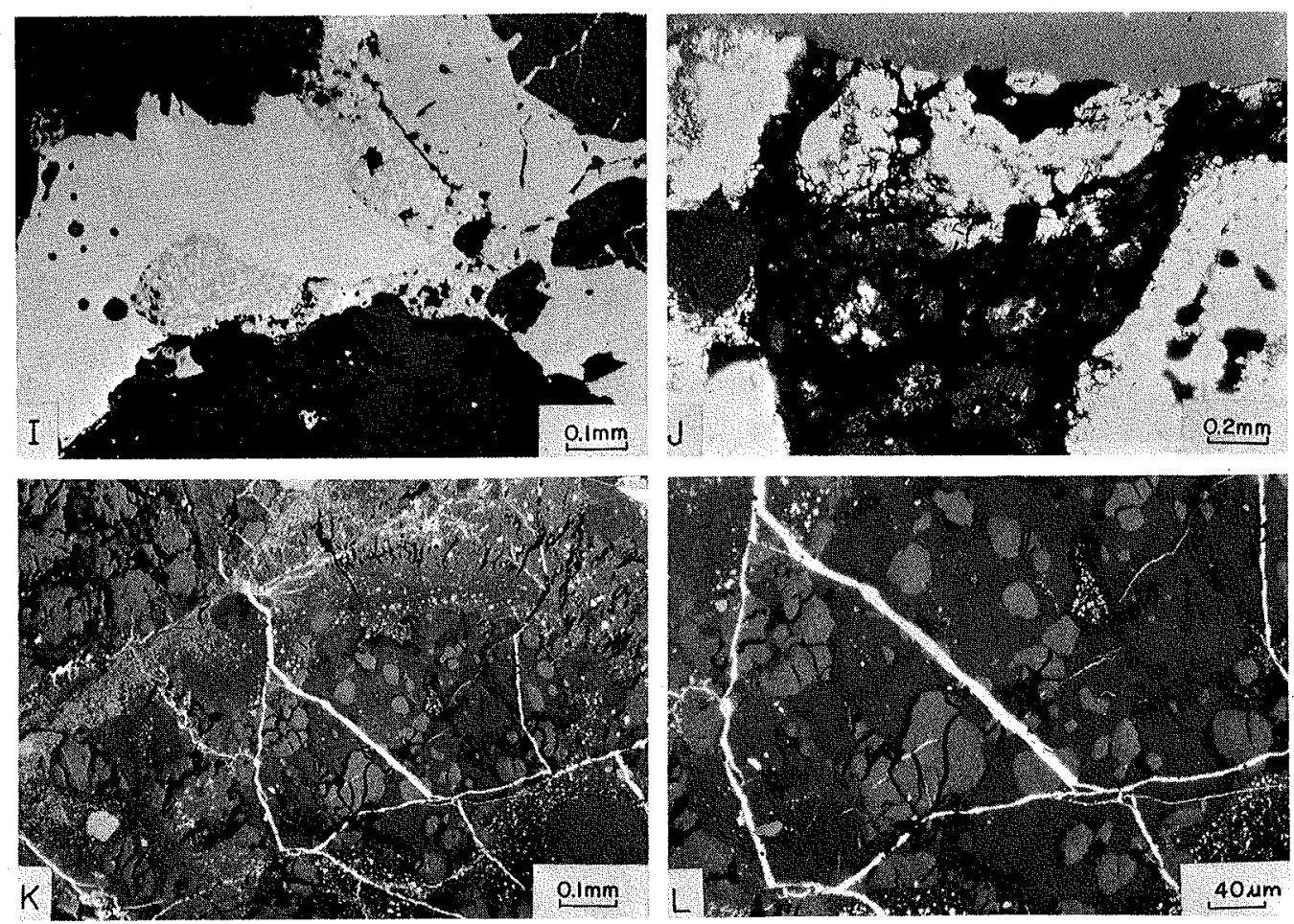

Figure 1 - A. Relict porphyritic chondrule, consisting mainly of olivine, from the light portions of the Paranaíba chondrite. Transmitted light, crossed nicols. . B. Elongated, relict chondrule, consisting of olivine (light gray) and fine-grained material (dark gray): Metallic nickel-iron (white) occurs mainly as irregular veins. Reflected light. C. Barred object (possibly a relict chondrule), consisting of olivine (light gray) and fine-grained material (dark gray). Reflected light. D. Shock vein (right to left) consisting of glass, isotropic and anisotropic olivine and orthopyroxene, and opaque minerals (white), either filling minute cracks or occurring as minute inclusions. Reflected light. Microprobe traverse carried out perpendicular to the shock vein is indicated by the line AB. E. Hand specimen view of the L6 chondrite Paranaíba, showing angular, subrounded to rounded light areas cut by black veins, giving the meteorite a pronounced breccia-like appearance. The black veins and areas are shock-produced and darkened light material, whereas the light areas are considerably less affected by shock and retain the original light color of the chondrite. F. Oligoclase glass (maskelynite), dark gray, surrounded by olivine grains, light gray, showing radial arrangment, in the light portions of Paranaiba. Reflected light. G. Same as Fig. 1F, but plane polarized transmitted light. Maskelynite is white in color. H. Droplets of chromite (white) within maskelynite (dark gray), in the light portions of Paranaíba. Olivine showing irregular fractures is light gray in color. Reflected light. I. Troilite (gray) in eutectic intergrowth with a large grain of metallic nickel-iron (white). Dark gray are silicates. From a dark shock vein of Paranaíba. Reflected light. J. Shock veins (dark) showing partially and completely isotropic grains of olivine (large grains, irregular fractures) and orthopyroxene composition. Transmitted light, crossed nicols. K. Small area within the shock vein shown in Fig. 1J, consisting of isotropic and anisotropic grains of olivine (light gray; slightly rounded and irregular in shape with minute black fissures cutting some grains) and orthopyroxene composition (medium gray; some grains are rounded in outline). Glass is dark gray (interstitial material), chromite is very light gray (isolated grains and also droplets within the glass), and metal is white (tiny particles unevenly distributed over the area or spread along the narrow fissures; in the interior of fissures, it is intergrown with troilite). Reflected light. L. Same as Fig. 1K, but higher magnification. Reflected light 
The Paranaíba fall was first reported by Arruda (1962) and Amaral (1962), who provided a preliminary description of its texture and mineralogical composition. The meteorite is also listed in Hey (1966), and Mason (1967), based on X-ray diffraction and optical microscopy, determined the composition of its olivine to be $\mathrm{Fa}_{23}$.

In the present paper, we present a detailed study of the meteorite by optical microscopy, X-ray, electron microprobe, and bulk chemical techniques. Special emphasis is given to the petrologic classification of the stone and to the study of its many black veins and their origin.

ANALYTICAL PROCEDURES The Paranaíba chondrite was examined optically in transmitted and reflected light. Its constituent phases were analyzed using electron microprobe techniques, and separated minerals from the black veins were subjected to X-ray diffraction analysis. The bulk composition of the stone was determined using the procedures described by Jarosewich (1966), with some small modifications for the minor elements.

Electron microprobe analyses were carried out using an ARL EMX-SM instrument, operated at $15 \mathrm{keV}$ accelerating potential, a sample current of approximately $0.02 \mu \mathrm{A}$, and an electron beam spot size of $\leq 1 \mu \mathrm{m}$. For glass analyses, the electron beam was defocused to approximately $100 \mu \mathrm{m}$ in diameter, the sample current was reduced to about $0.015 \mu \mathrm{A}$, and the sample moved continuously to avoid excessive heat build-up. Corrections were made for instrumental drift, background, and differential matrix effects, following the method by Bence and Albee (1968). Compounds of well known composition were used as standards, i.e. olivine Marjalahti and Suzimaki, augite A-209, bronzite A-214, andesine AC-362, albite Amelia, orthoclase Or-1, chromite G53IN8, and synthetic glass G135B3.

GENERAL DESCRIPTION In hand specimen, the Paranaíba meteorite exhibits a very conspicuous structure, consisting of angular, subrounded to rounded light fragments cut by black veins and broad black areas. The light fragments vary in size; in the specimen available for the present study, the light areas are at least $1-10 \mathrm{~mm}$ in size, with the dark vein areas being of the same order of magnitude (Fig. 1E). The light areas are recrystallized, with only few relict chondrules discernible (Figs. 1A-C). The dark areas, which are often perfectly straight veins (Fig. 1D) or sometimes irregular dark patches (Fig. 1E), are clearly produced from the light material by shock melting. They consist of glass, droplets and veins of metallic nickel-iron and troilite (often as an eutectic intergrowth), as well as isotropic phases of olivine and orthopyroxene composition and do not contain any discernible chondrules. The dark color of the veins is the result of the abundance of very fine-grained opaque phases, largely metallic nickel-iron and troilite. The meteorite is, thus, best characterized as a monomict breccia (Amaral, 1962) of shock origin.

MINERALOGY OF THE LIGHT PORTIONS The light portions of the Paranaiba chondrite represent the less shock-altered portions of the meteorite and, thus, provide the best insight into its original mineralogy, petrology, and classification. The dark portions, on the other hand, represent highly shock-transformed and shock-melted light material and, thus, illustrate the severity of the secondary alteration of the original chondrite material.

The light portions of the chondrite consist of major olivine and orthopyroxene, minor oligoclase glass (maskelynite), metallic nickel-iron and troilite, and accessory chromite and ilmenite. 
Olivine This mineral is the major phase of the meteorite, occurring in relict chondrules and in the matrix. Its composition is identical in chondrules and matrix and is quite homogeneous $\left(\mathrm{Fa}_{22.6-24.8} ;\right.$ mean $\left.\mathrm{Fa}_{23.7}\right)$ (Table I). It is typical in composition for olivine of L-group chondrites, as is indicated by comparison to the ranges for average olivine compositions of L-group chondrites (Fig. 2; Keil and Fredriksson, 1964, as revised by Fodor et al., 1976).

Table I - Average compositions, as determined by electron microprobe techniques, of olivine, bronzite, oligoclase glass (maskelynite) and chromite in the light portions of Paranaiba (in weight per cent). Number of grains analyzed are shown in parentheses

\begin{tabular}{|c|c|c|c|c|c|c|c|c|c|c|c|c|}
\hline & & oliv & ine & & Bronzi & ite & & $\begin{array}{l}\text { O1igoclas } \\
\text { (maskely }\end{array}$ & $\begin{array}{l}\text { e glass } \\
\text { ynite) }\end{array}$ & & Chrom: & \\
\hline & & $(20)$ & S.D. & & (26) & S.D. & & (12) & S.D. & & (18) & S.D. \\
\hline $\mathrm{SiO}_{2}$ & & 38.4 & 0.3 & & 54.1 & 0.4 & & 66.2 & 0.7 & & 0.68 & 0.09 \\
\hline $\mathrm{TiO}_{2}$ & & n.d. & - & & 0.18 & 0.03 & & n.d. & - & & 2.80 & 0.26 \\
\hline $\mathrm{Al}_{2} \mathrm{O}_{3}$ & & 0.08 & 0.04 & & 0.27 & 0.08 & & 21.4 & 0.4 & & 5.5 & 0.2 \\
\hline $\mathrm{Cr}_{2} \mathrm{O}_{3}$ & & n.d. & - & & 0.11 & 0.03 & & n.d. & - & & 54.6 & 0.5 \\
\hline$V_{2} O_{3}$ & & n.d. & - & & n.d. & - & & n.d. & - & & 0.65 & 0.04 \\
\hline $\mathrm{FeO}$ & & 21.8 & 0.5 & & 13.9 & 0.6 & & 0.25 & 0.09 & & 32.4 & 0.5 \\
\hline $\mathrm{MnO}$ & & 0.45 & 0.03 & & 0.46 & 0.02 & & n.d. & - & & 0.92 & 0.09 \\
\hline $\mathrm{MgO}$ & & 39.3 & 0.3 & & 29.2 & 0.3 & & n.d. & - & & 3.03 & 0.23 \\
\hline $\mathrm{CaO}$ & & 0.11 & 0.04 & & 0.90 & 0.12 & & 2.24 & 0.15 & & 0.09 & 0.03 \\
\hline $\mathrm{Na}_{2} \mathrm{O}$ & & n.d. & - & & 0.06 & 0.02 & & 9.1 & 0.4 & & n.d. & - \\
\hline $\mathrm{K}_{2} \mathrm{O}$ & & n.d. & - & & n.d. & - & & 0.94 & 0.03 & & n.d. & - \\
\hline TOTAL & & 100.14 & & & 99.18 & & & 100.13 & & & 100.67 & \\
\hline & & & & Numbe & er of ions & 5 on & the & basis of & & & & \\
\hline & & $0=4$ & & & $0=6$ & & & $0=32$ & & & $0=32$ & \\
\hline S1 & & 0.996 & & & 1.960 & & & 11.617 & & & 0.192. & \\
\hline $\mathrm{Ti}$ & & - & & & 0.005 & & & - & & & 0.595 & \\
\hline Al & & 0.002 & & & 0.012 & & & 4.434 & & & 1.830 & \\
\hline $\mathrm{Cr}$ & & - & & & 0.003 & & & - & & & 12.191 & \\
\hline v & & - & & & - & & & - & & & 0.147 & \\
\hline $\mathrm{Fe}$ & & 0.473 & & & 0.421 & & & 0.037 & & & 7.651 & \\
\hline Mn & & 0.010 & & & 0.014 & & & - & & & 0.220 & \\
\hline $\mathrm{Mg}$ & & 1.519 & & & 1.577 & & & - & & & 1.275 & \\
\hline $\mathrm{Ca}$ & & 0.003 & & & 0.035 & & & 0.421 & & & 0.027 & \\
\hline - $\mathrm{Na}$ & & - & & & 0.004 & & & 3.105 & & & - & \\
\hline K & & - & & & - & & & 0.211 & & & - & \\
\hline $\begin{array}{l}z \\
x \\
\text { sum }\end{array}$ & & $\begin{array}{l}0.996 \\
2.007 \\
3.003\end{array}$ & & & $\begin{array}{l}1.980 \\
2.051 \\
4.031\end{array}$ & & & $\begin{array}{r}16.051 \\
3.774 \\
19.825\end{array}$ & $\mathrm{sum}_{\mathrm{Sum}^{+2}}^{+3}$ & & $\begin{array}{r}14.955 \\
9.173 \\
24.128\end{array}$ & \\
\hline & $\begin{array}{l}\text { Fo } \\
\mathrm{Fa}\end{array}$ & $\begin{array}{l}76.3 \\
23.7\end{array}$ & . & $\begin{array}{l}\text { En } \\
\text { Fs } \\
\text { Wo }\end{array}$ & $\begin{array}{r}77.6 \\
20.7 \\
1.7\end{array}$ & & $\begin{array}{l}O r \\
A b \\
A n\end{array}$ & $\begin{array}{r}5.6 \\
83.1 \\
11.3\end{array}$ & 1 & $\begin{array}{l}\text { Uv } \\
\mathrm{Cm} \\
\mathrm{He} \\
\mathrm{Sp}\end{array}$ & $\begin{array}{r}7.7 \\
80.3 \\
7.0 \\
4.9\end{array}$ & \\
\hline
\end{tabular}


Pyroxene This phase occurs in relict chondrules and in the matrix and is identical in composition in both. It is bronzite in composition and ranges from $\mathrm{Fs}_{19.6-21.8}$ (mean $\mathrm{Fs}_{20.7}$ ) (Table I). Its compositional range is well within the ranges for average orthopyroxene composition given by Keil and Fredriksson (1964), as revised by Fodor et al. (1976) (Fig. 2).

Oligoclase glass (maskelvmile) Isotropic material of oligoclase composition is found as clear grains in the matrix (Figs. 1F, G), usually containing small inclusions of olivine and pyroxene. It is often associated with olivine of radiating texture (Figs. 1F,G) and is of shock origin. Maskelynite is relatively homogeneous, averaging $\mathrm{Or}_{5: 6} \mathrm{Ab}_{83.1} \mathrm{An}_{11.3}$. The composition of the maskelynite is consistent with that of oligoclase from L-group chondrites (Van Schmus and Ribbe, 1968).

Chromite This mineral occurs as irregular, often fractured grains in the matrix of the light portions of the meteorite. In the dark portions, chromite is found as small, isolated grains within the shock veins. In a few cases, chromite droplets are found within maskelynite (Fig. 1H). Compositionally, chromite is uniform and homogeneous (Table I) and in agreement with the ranges given by Bunch et al. (1967) for chromite from L-group chondrites.

One grain of ilmenite was detected with the electron microprobe.

Metallic nickel-iron and troilite Kamacite, taenite and troilite are minor phases in this metenrite, with kamacite being the dominant phase. Nickel-iron and troilite are frequently in contact and, in the dark, highly shocked areas, eutectic intergrowth of the two phases is common (Fig. 1I).
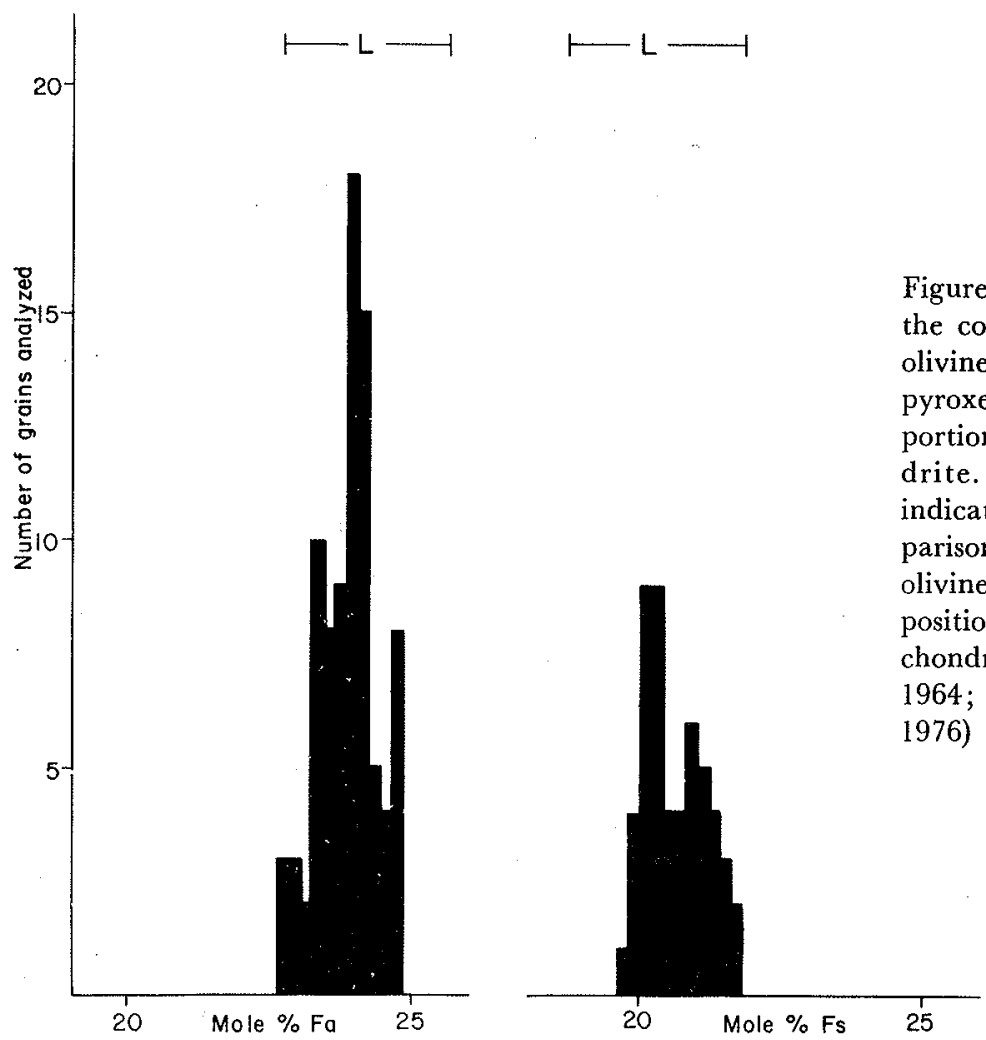

Figure 2 - Histograms showing the compositions (in mole \%) of olivine $\left(\mathrm{Fa} ; \mathrm{Fe}_{2} \mathrm{SiO}_{4}\right)$ and orthopyroxene $\left(\mathrm{Fs} ; \mathrm{FeSiO}_{3}\right)$ in the light portions of the Paranaíba chondrite. L-group classification is indicated for Paranaíba by comparison to the ranges of average olivine and orthopyroxene compositions in equilibrated L-group chondrites (Keil and Fredriksson, 1964; as revised by Fodor et al., 1976) 
BULK GHEMICAL COMPOSITION The bulk chemical analysis and the CIPW molecular norm are listed in Table II. For this analysis, $16 \mathrm{~g}$ of meteorite were selected randomly, thus, thẽ analyzed sample is a mixture of light and dark portions, possibly containing a little more light material.

The bulk chemical analysis confirms the conclusions derived from the data on the mineral compositions, indicating that the meteorite belongs to the L-group. Specifically, L-group classification is indicated by the ratios of $\mathrm{Fe}^{0} / \mathrm{Ni}^{0}(5.05), \mathrm{Fe}_{\text {total }} / \mathrm{SiO}_{2}(0.52)$, and $\mathrm{Fe}^{0} / \mathrm{Fe}_{\text {total }}(0.31)$, which are very close to the averages for L-group chondrites given by Craig (1964) ( $\left.\mathrm{Fe}^{0} / \mathrm{Ni}^{0} 6.87\right)$ and Van Schmus and Wood (1967) $\left(\mathrm{Fe}_{\text {total }} / \mathrm{SiO}_{2} 0.55 ; \mathrm{Fe}^{0} /\right.$ $\left./ \mathrm{Fe}_{\text {tqtal }} 0.33\right)$. L-group classification is also indicated by the contents of $\mathrm{Fe}_{\text {total }}(20.86 \%)$ and metallic nickel-iron content $(7.92 \%)$, which are in agreement with L-group averages by Craig (1964) $\left(\mathrm{Fe}_{\text {total }} 21.82 \%\right)$ and Keil $(1962 \mathrm{a}, \mathrm{b})$ (total metallic nickel-iron 6.85\%).

The CIPW molecular norm confirms the microscopical results, namely that olivine and orthopyroxene are major, plagioclase, metallic nickel-iron and troilite are minor, and chromite and ilmenite are accessory constituents of the chondrite. However, diopside and apatite indicated in the norm in minor and accessory amounts, respectively, could not be confirmed in the mode.

Table II - Bulk chemical analysis and CIPW norm of the Paranaíba chondite

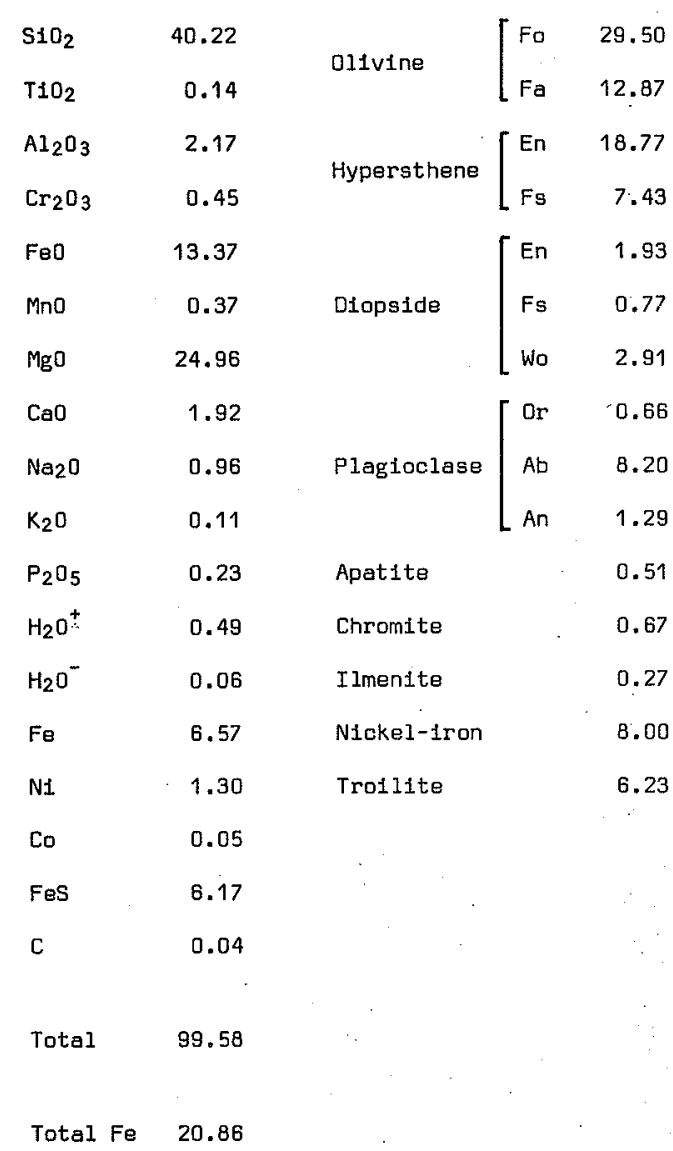


SHOCK METAMORPHISM The most conspicuous features of the Paranaíba chondrite are the black veins and black areas that cut through the meteorite. They consist of dust-fine to vein-like metallic nickel-iron and troilite assemblages which often fill irregular cracks and cleavages (Figs. 1J-L), in a silicate matrix. The veins are straight (Fig. 1D), or form irregular patches and areas (Figs. 1E,K,L). Besides metallic nickel-iron and troilite, these veins contain olivine, orthopyroxene, glass, and chromite (Fig. 3). However, optical microscopy indicates that within any one vein, olivine and orthopyroxene may be anisotropic, weakly anisotropic, or perfectly isotropic. This transition is not only seen from grain to grain, but even within single grains, i.e. part of a single grain may be anisotropic, another weakly anisotropic, still another isotropic. Thus, the shock waves which are responsible for producing the veins travelled irregularly through the rock, i.e. produced pressure gradients and, thus, dark veins as a result of high pressures in certain parts of the meteorite, whereas others were less affected by shock and, thus, remained light. Similar pressure gradients are also observed within single veins and even within single mineral

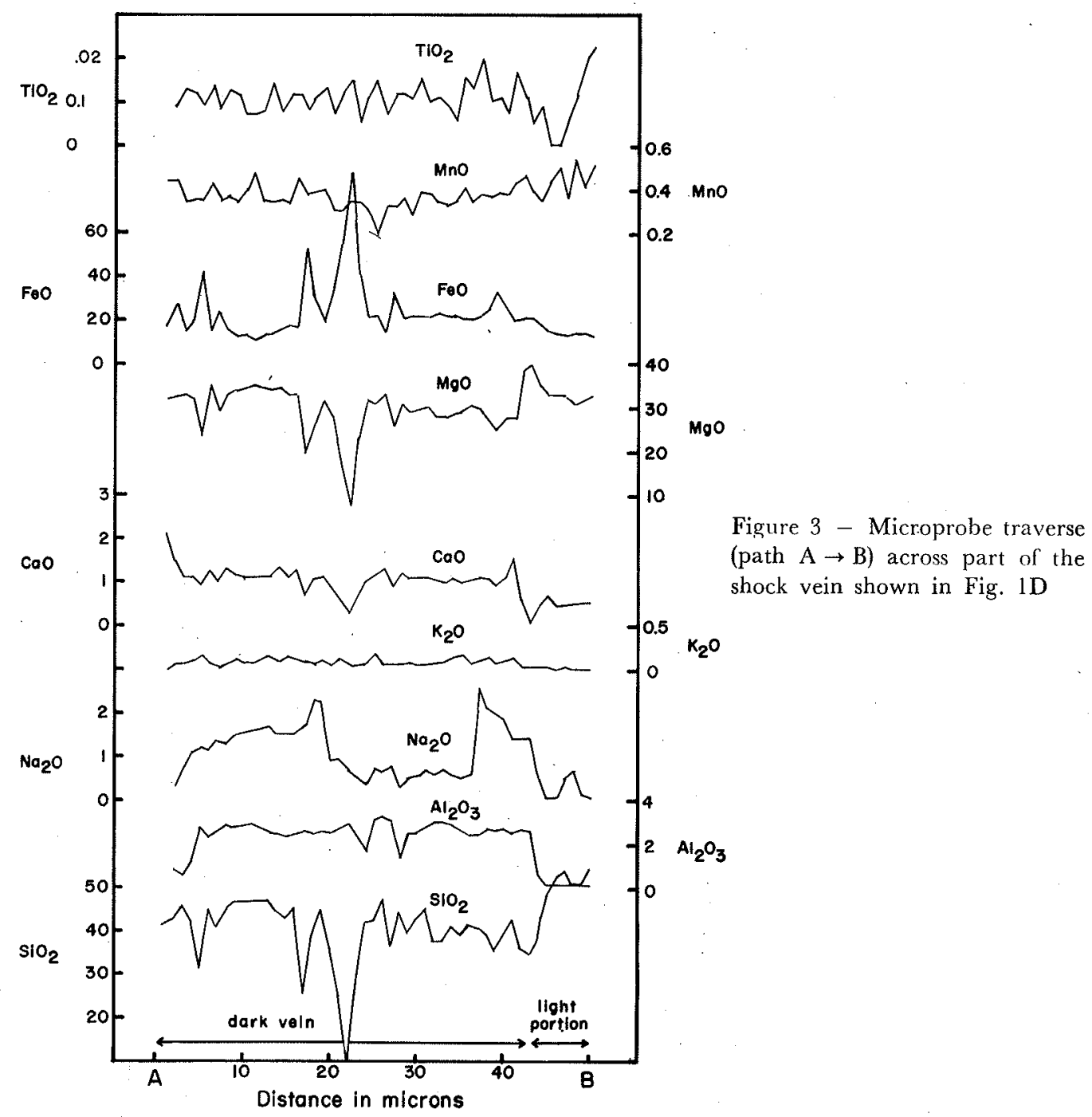


grains. The isotropic silicates are often perfectly colorless in transmitted light, but sometimes are light to dark brown in color.

In an attempt to derive at an estimate of minimum pressures responsible for the formation of the shock veins in Paranaíba, consideration must be given to reports by others on similarly veined chondrites, and on shock transformation of silicate minerals in general. That black veins in chondrites are the result of intensive shock modification has been shown experimentally by Fredriksson et al. (1963), who exposed the unveined chondrite Ställdalen to shock pressures in the ranges of $150-300$ and $.500-800 \mathrm{kbars}$ for about $0.5 \mu \mathrm{s}$. In both cases, black veins were formed, and the sample exposed to the higher shock pressures was transformed into an entirely black chondrite. A great deal of data has been published dealing with static and shock transformation of minerals (e.g. Stöffler, 1972). However, a number of studies of plagioclase, olivine, and orthopyroxene in meteorites are particularly relevant to the origin of the dark veins in Paranaiba. Specifically, isotropic material of plagioclase composition was first discovered in achondrites and chondrites by Tschermak (1872, 1883), who interpreted it as remelted or otherwise transformed plagioclase glass and named it maskelynite. Binns (1967) described maskelynite from many chondrites, most of which exhibit dark veins. Milton and De Carli (1963) produced maskelynite by explosion shock and solid state transformation as pseudomorphs of plagioclase in the pressure range of 250-300 kbars. At higher pressures (600-800 kbars), the temperature was raised considerably above the melting point of plagioclase and a plagioclase glass formed by fusion. Milton and De Carli (1963) suggest to apply the name maskelynite only to such isotropic materials of plagioclase composition that clearly formed by solid state transformation of plagioclase under high shock pressures, and not by fusion. We concur with this suggestion, particularly in view of the fact that isotropic plagioclase of solid state transformation origin has distinctly different properties (e.g. refractive indices, infrared absortion spectra) than isotropic plagioclase formed by shock fusion (Stöffer and Hornemann, 1972). These authors also showed that solid state transformation of feldspar occurs in the $300-450 \mathrm{kbar}$ pressure range and that fusion occurs at pressures exceeding $430 \mathrm{kbars}$, in general agreement with the results of Milton and De Carli (1963).

The oligoclase in the light portions of Paranaíba seems to be stoichiometric and, thus, volatile elements such as $\mathrm{Na}$ and $\mathrm{K}$ do not appear to have escaped in the glass-forming process. Furthermore, there are no indications of eutectic melting of metallic nickel-iron and troilite in the light portions, a process that would take place at about $900{ }^{\circ} \mathrm{C}$ (Kullerud et al., 1969). In addition, the oligoclase glass does not show vesicles, flow structures, or other indications of fusion. Since formation of oligoclase glass by shock fusion would probably result in the loss of some volatile elements and since it would require temperatures of the order of $1500-1700^{\circ} \mathrm{C}$ (Stöfler and Hornemann, 1972) and would most likely result in formation of vesicles, flow structures and other indicators of fusion in the glass, we conclude that the oligoclase glass formed by solid state shock transformation and, thus, the material is properly referred to as maskelynite. The estimates for the pressures required for this transition to take place range from 250-300 kbars (Milton and De Carli, 1963) to 300-450 kbars (Stöffler and Hornemann, 1972), but in view of the apparently relatively low temperatures $\left(<900^{\circ} \mathrm{C}\right)$, shock pressures were probably in the lower ranges of these estimates.

In the dark veins, on the other hand, melting clearly took place, resulting in the forformation of eutectic NiFe-FeS intergrowths (Figs. 1I) and alkali-rich, iron-magnesium-bearing silicate glasses (Figs. 1D, J-L; 3). The temperatures required for fusion of oligoclase, olivine, and pyroxene by shock are high $\left(1500-1700^{\circ} \mathrm{C}\right)$, and require shock pressures in excess of $340 \mathrm{kbars}$ (Stöffler and Hornemann, 1972). 
Table III - Electron microprobe analyses (in weight percent) and structural formulae of optically isotropic grains of olivine composition liwm dark shock veins of Paranaíba

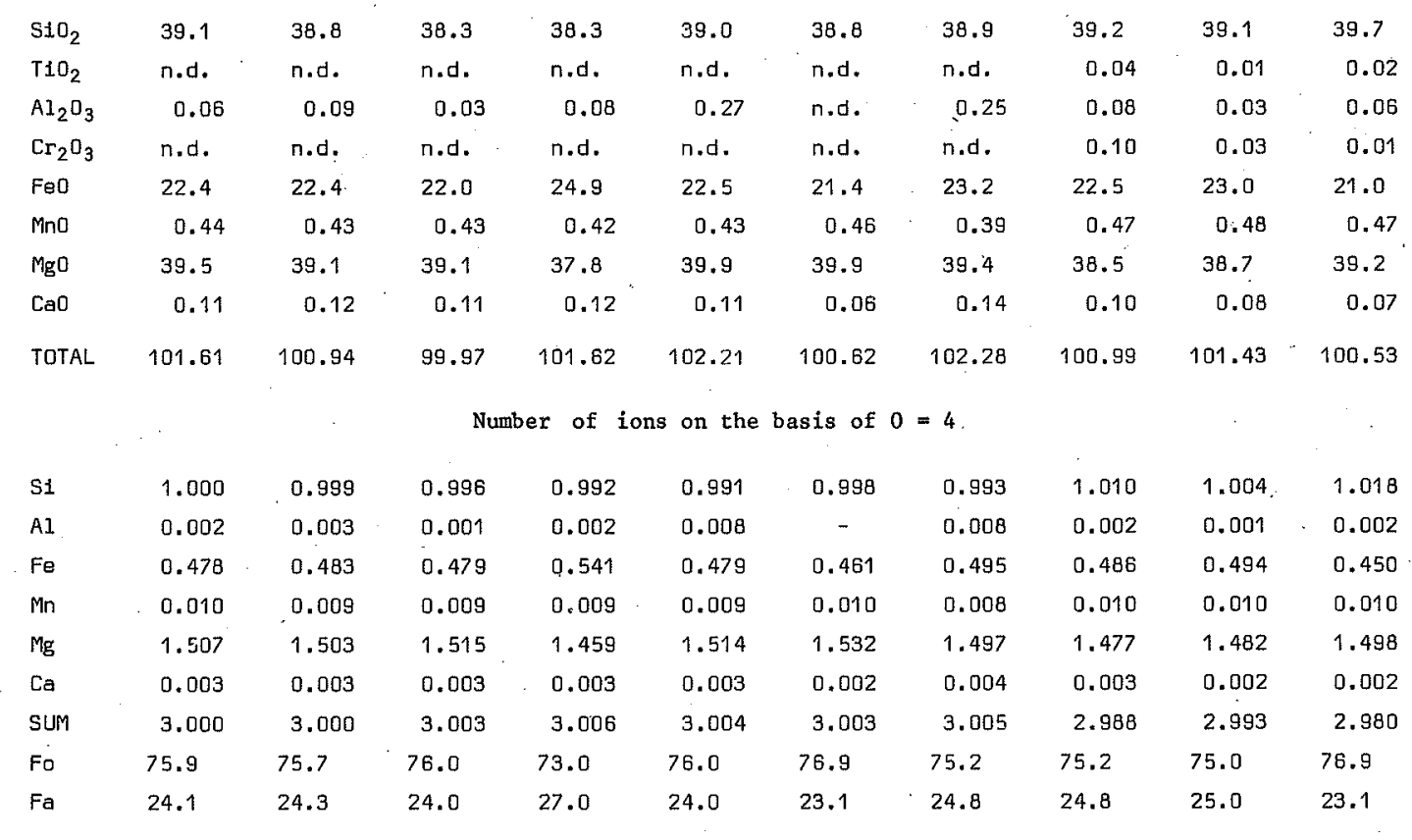

n.d. - Not determined

The optically isotropic grains of olivine (Table III) and orthopyroxene (Table IV) composition in the black veins also indicate high shock pressures. Unfortunately, only approximate pressure estimates can be made at this time because our attempts to separate the isotropic grains from the veins and to identify their structures by X-ray diffraction have thus far been unsuccessful. Laboratory studies of high-pressure transformation of olivine and pyroxene into optically isotropic phases with spinel structure have been carried out by Ringwood and Major (1966a, b), and require pressures on the order of 150-200 kbars (at $900{ }^{\circ} \mathrm{C}$ ). In shock-metamorphosed meteorites very similar in appearance to the Paranaíba chondrite (Tenham, Coorara), the new minerals ringwoodite and majorite were discovered in shock veins (Binns et al., 1969; Binns, 1970; Smith and Mason, 1970). Ringwoodite is an optically isotropic phase of olivine composition but is converted into the cubic spinel structure and requires $>450$ kbars of shock pressure for its formation (Stöffler, 1972). Majorite is an isotropic phase of pyroxene composition but cubic garnet structure and requires > 135 kbars of shock pressure for its formation (Stöffler, 1972). The mineral ringwoodite is characteristically purple in color, whereas the isotropic olivine in Paranaíba is colorless. Thus, in Paranaíba the isotropic olivine does not appear to be ringwoodite. Majorite is described as brown in color (Smith and Mason, 1970) and, indeed, some isotropic grains of pyroxene composition in Paranaíba are of that color. However, in view of the lack of X-ray diffraction evidence, majorite cannot be identified with certainty as a constituent of the Paranaíba shock veins.

The absence of ringwoodite and the presence of another isotropic phase of olivine composition in Paranaiba in view of the high ( $\geq 430$ kbars) shock pressures indicated by the occurrence of alkali-rich glass of shock fusion origin is noteworthy. We speculate that 


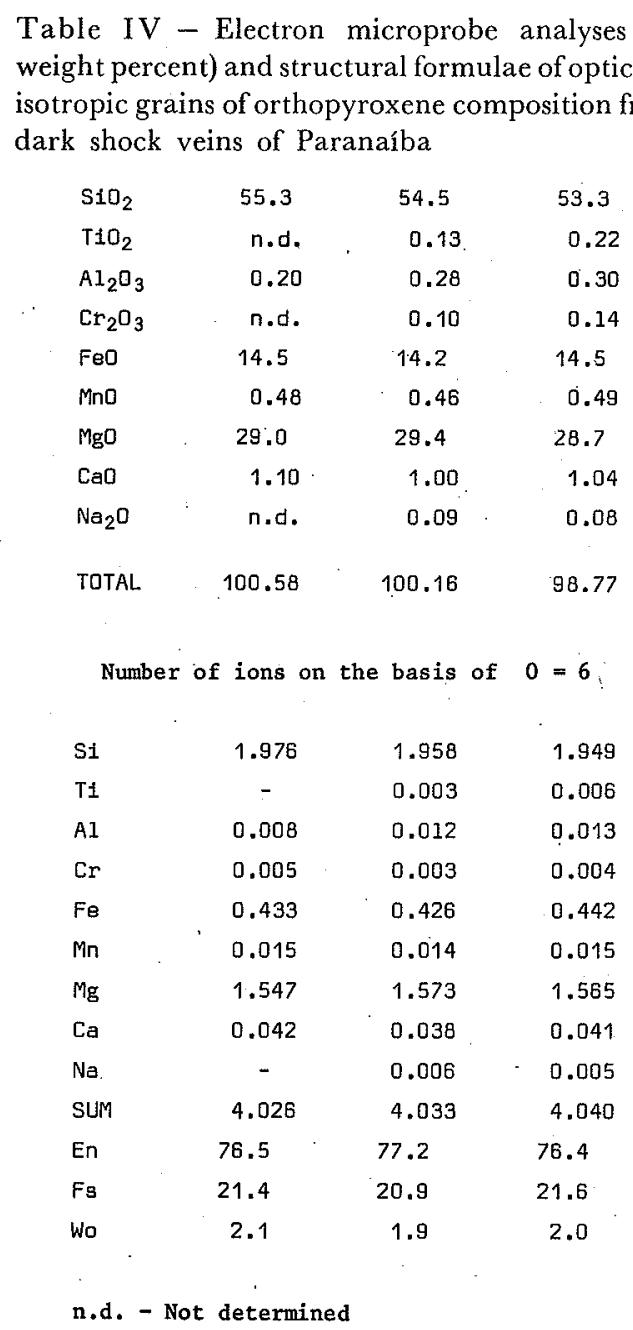

the high temperatures (1500-1 $700^{\circ} \mathrm{C}$, Stöffler and Hornemann, 1972) required for the formation of alkali-rich glass involving melting of oligoclase, olivine, and pyroxene (Fig. 3) by shock fusion were so high as to not allow temperature quenching and, thus, ringwoodite may have converted into some other (metastable) isotropic phase of olivine composition. However, X-ray data on the phase in Paranaíba are required before this speculation can be verified.

CONCLUSIONS On the basis of the mineral compositions, particularly olivine $\left(\mathrm{Fa}_{23.7}\right)$, orthopyroxene $\left(\mathrm{Fs}_{20.7}\right)$ and chromite, and the bulk chemical composition, especially the ratios $\mathrm{Fe}^{0} / \mathrm{Ni}^{0}(5.05), \mathrm{Fe}_{\text {total }} / \mathrm{SiO}_{2}(0.52)$, and $\mathrm{Fe}^{0} / \mathrm{Fe}_{\text {total }}(0.31)$, and the contents of $\mathrm{Fe}_{\text {total }}$ $(20.86 \%)$ and metallic nickel-iron $(7.92 \%)$, the Paranaíba meteorite is classified as an L-group chondrite. The homogeneous and uniform compositions of the ferromagnesian minerals, the scarcity of chondrules, and the high degree of recrystallization of the matrix indicate that the meteorite belongs to the petrologic class L6 of Van Schmus and Wood (1967). 
The dark veins and areas of the meteorite were formed by extensive shock alteration, (>430 kbars; $1500-1700^{\circ} \mathrm{C}$ ), with the angular to subrounded and rounded light fragments representing the less altered portions of the rock $\left(\sim 200 \mathrm{kbars},<900^{\circ} \mathrm{C}\right)$ as is indicated by the presence of maskelynite. Within the veins, olivine and pyroxene are transformed into optically isotropic grains of essentially unchanged composition. Considerable pressure gradients are indicated not only on the hand-specimen scale, but also on the micron scale, i.e. even individual olivine and pyroxene grains may in part be isotropic, in others weakly to strongly anisotropic. The isotropic phase of olivine composition is not ringwoodite, and the isotropic phase of pyroxene composition cannot confidently by identified as majorite because of the lack of X-ray diffraction data.

Acknowledgements We are grateful to Dr. Sérgio E. Amaral for making the meteorite available for study. This work is supported by a Fulbright-Hayes travel grant to E. Kirchner; a travel grant by Fundação de Amparo à Pesquisa do Estado de São Paulo (Geologia 707/1975) to G. B. Gomes; and by the National Aeronautics and Space Administration, Grant NGL 32-004-064 (K. Keil, Principal Investigator).

\section{REFERENCES}

AMAR.IL, S.E. - 1962 - Nota preliminar sobre um meteorito caído no sul de Mato Grosso. Bol. Soc. Bras. Geol. 11: 5-19

ARRUDA, M. R. - 1962 - Meteorito Can-Can e sua composição mineralógica. Ciência e Cultura 14: 154

BENGE, A. E. and ALBEE, A. L. - 1968 - Empirical correction factors for the electron microanalysis of silicates and oxides. J. Geol. 76: 382-403

BINNS, R. A. - 1967 - Stony meteorites bearing maskelynite. Nature 213: $1111-1112$

BINNS, R. A. - $1970-\left(\mathrm{Mg}, \mathrm{Fe}_{2} \mathrm{SiO}_{4}\right.$ spinel in a meteorite. Phys. Earth Planet. Interiors 3 : $156-160$

BINNS, R. A., DAVIS, R. J. and REED, S. J. B. - 1969 - Ringwoodite, natural (Mg, Fe) ${ }_{2} \mathrm{SiO}_{4}$ spinel in the Tenham meteorite. Nature 221: 943-944

BUNCH, T. E., KEIL, K. and SNETSINGER, K. G. - 1967 - Chromite composition in relation to chemistry and texture of ordinary chondrites. Geochim. Cosmochim. Acta 31: 1569-1 582

CRAIG, H. - 1964 - Petrological and compositional variations in meteorites. In: Isotopic and Cosmic Chemistry, p. 401. North-Holland Publ. Co., Amsterdam

FODOR, R. V., KEIL, K., WILKENING, L. L., BOGARD, D. D. and GIBSON, E. K. - 1976 Origin and history of a meteorite parent-body regolith breccia: Carbonaceous and noncarbonaceous lithic fragments in the Abbott, New Mexico, chondrite. New Mexico Geol. Soc., Spec. Publ. 6: 206-218

FREDRIKSSON, K., DE CARLI, P. S. and AARAMA'E, A. - 1963 - Shock-induced veins in chondrites. In: Priester, Ed., Space Research III : 974-983. North-Holland Publ. Co., Amsterdam

HEY, M. H. - 1966 - Catalogue of meteorites. British Museum, 3rd. Ed., London.

JAROSEWICH, E. - 1966 - Chemical analyses of ten stony meteorites. Geochim. Cosmochim. Acta 30: $1261-1265$

KEIL, K. - 1962a - On the phase composition of meteorites. J. Geophys. Res. 67: 4055-4061

KEIL, K. - 1962b - Quantitativ-erzmikroskopische Integrationsanalyse der Chondrite. Chem. Erde 22: 281-348

KEIL, K. and FREDRIKSSON, K. - 1964 - The iron, magnesium, and calcium distribution in coexisting olivines and rhombic pyroxenes of chondrites. J. Geophys. Res. 69: $3487-3515$

KULleRUD, G., YUND, R. A. and MOH, G. H. - 1969 - Phase relations in the Cu-Fe-S, Cu-Ni-S, and Fe-Ni-S systems. In "Magmatic Ore Deposits" (ed. H. D. B. Wilson), Econ. Geol., Monogr. 4: 323-343

MASON, B. - 1967 - Olivine composition in chondrites - a supplement. Geochim. Cosmochim. Acta 31: 1 100-1 103 
MILTON, D.J. and DE CARLI, P.S. - 1963 - Maskelynite: formation by explosive shock. Science 140: 670-671

RINGWOOD, A. E. and MAJOR, A. - 1966a - Synthesis of $\mathrm{Mg}_{2} \mathrm{SiO}_{4}-\mathrm{Fe}_{2} \mathrm{SiO}_{4}$ spinel solid solutions. Earth Planet. Sci. Lett. 1: 241-245

RINGWOOD, A. E. and MAJOR, A. - 1966 - High-pressure transformation in pyroxenes. Earth Planet. Sci. Lett. 1: 351-357

SMITH, J. V. and MASON, B. - 1970 - Pyroxene-garnet transformation in Coorara meteorite. Science 168: 832-833

STÖFFLER, D. - 1972 - Deformation and transformation of rock-forming minerals by natural and experimental shock processes. I. Behavior of minerals under shock compression. Fortschr. Miner. 49: 50-113

STÖFFLER, D. and HORNEMANN, U. - 1972 - Quartz and feldspar glasses produced by natural and experimental shock. Meteoritics 7: 371-394

TSCHERMAK, G. - 1872 - Die Meteoriten von Shergotty and Gopalpur. Sitzber. Akad. Wiss. Wien 55: 122-145

TSCHERMAK, G. - 1883 - Beitrag zur Classification der Meteoriten. Sitzber.Akad. Wiss. Wien 85: $347-371$

VAN SCHMUS, W. R. and WOOD, J. A. - 1967 - A chemical-petrologic classification for the chondritic meteorites. Geochim. Cosmochim. Acta 31: 747-765

VAN SCHMUS, W. R. and RIBBE, P. H. - 1968 - The composition and structural state of feldspar from chondritic meteorites. Geochim. Cosmochim. Acta 32: $1327-1342$ 